\title{
The future of the indigenous freshwater crayfish Austropotamobius italicus in Basque Country streams: Is it possible to survive being an inconvenient species?
}

\author{
L. García-Arberas ${ }^{(1)}$, A. Rallo(1), A. Antón ${ }^{(1)}$ \\ Received September 29, 2009 / Reçu le 29 septembre 2009 \\ Revised April 26, 2010 / Révisé le 26 avril 2010 \\ Accepted April 29, 2010 / Accepté le 29 avril 2010
}

\section{ABSTRACT}

Key-words: $\quad$ The white-clawed freshwater crayfish Austropotamobius italicus is listed native freshwater crayfish, SWOT analysis, Iberian

Peninsula, threatened species, management as "vulnerable" in the Spanish Red List of threatened species, but local legislation varies among Spanish regions. Thus, while in some places the species is classified as "in risk of extinction" and various plans of conservation and restoration have been implemented, in the Basque Country and other regions the species is not listed. The distribution of the whiteclawed crayfish in the province of Biscay (Basque Country) was studied from 1993 to 2007 at more than 600 sampling locations. Results show that 108 streams were inhabited by the native crayfish species $A$. italicus while 137 streams were inhabited by non-native signal crayfish Pacifastacus leniusculus or red-swamp crayfish Procambarus clarkii. The spread of nonnative crayfish is not the only threat to the native species whose survival is also closely dependent on how watersheds are managed. Most $A$. italicus populations inhabit headwaters, where forestry activities are very important. The presence of native crayfish in heavily forested areas results in a conflict of interests and makes its conservation particularly difficult. We employed a SWOT analysis - an assessment and decision tool commonly used in marketing and business - to evaluate the situation of the native white-clawed crayfish in Biscay, a province characterized by very high demographic pressure. SWOT analysis has proved to be a useful diagnostic tool and can help develop better and more accurate management strategies for the conservation of native crayfish threatened by multiple stressors.

RÉSUMÉ

Le futur de l'écrevisse à pattes blanches indigène Austropotamobius italicus dans les rivières du pays basque : Est-il possible de survivre en étant une espèce gênante?

Mots-clés : écrevisse indigène, analyse SWOT, Péninsule Ibérique,
L'écrevisse à pattes blanches Austropotamobius italicus est listée comme "vulnérable " dans la liste rouge espagnole des espèces en danger, mais la législation locale varie d'une région espagnole à l'autre. Alors que dans certains endroits l'espèce est classée "en risque d'extinction" et que différents plans de conservation et de réhabilitation sont mis en place, dans la Région Basque et d'autres régions l'espèce n'est sur aucune liste. La distribution de l'écrevisse

(1) Department of Zoology and Animal Cell Biology, University of the Basque Country, UPVIEHU, PO Box 644, E-48080 Bilbao, Spain, loreto.garcia@ehu.es 
espèces menacées, gestion à pattes blanches dans la province de Biscaye (Région Basque) a été étudiée de 1993 à 2007 dans plus de 600 sites échantillonnés. Les résultats montrent que 108 rivières sont occupées par l'espèce indigène $A$. italicus et que 137 rivières sont occupées par des espèces non-indigènes, l'écrevisse signal Pacifastacus leniusculus ou l'écrevisse de Louisiane Procambarus clarkii. La dispersion des espèces allochtones n'est pas la seule menace sur l'espèce native dont la survie dépend également de la manière dont les bassins versants sont gérés. La plupart des populations d'A. italicus occupent les têtes de bassin où les activités forestières sont très importantes. La présence d'écrevisses indigènes dans les zones très forestières conduit à un conflit d'intérêts et rend sa conservation particulièrement difficile. Nous avons employé l'analyse SWOT, un outil d'évaluation et de décision couramment utilisé en marketing et affaires, pour évaluer la situation de l'écrevisse à pattes blanches en Biscaye, une province caractérisée par une forte pression démographique. L'analyse SWOT est un outil de diagnostic utile. Elle peut aider à développer de meilleures stratégies de gestion pour la conservation des écrevisses indigènes menacées par de multiples stresseurs.

\section{INTRODUCTION}

Three species of freshwater crayfish can be found in Basque Country streams (Northern Iberian Peninsula): the indigenous white-clawed crayfish (ICS) Austropotamobius italicus (known until recently as $A$. pallipes) and the non-indigenous (NICS) signal crayfish Pacifastacus leniusculus (Dana, 1852) and red-swamp crayfish Procambarus clarkii (Girard, 1852). While the red-swamp crayfish was introduced in an uncontrolled way from aquaculture facilities, the signal crayfish was introduced deliberately by the local Administration since the early 1980 s into many streams that were either without decapods, or inhabited only by P. clarkii. The introduction of the signal crayfish into waters devastated by aphanomycosis or depleted by pollution or habitat alteration was made not only to restore a traditional fishing resource but also as an attempt to reduce the expansion of red swamp crayfish populations and to control river vegetation (Matthews et al., 1993; Ackefors, 1999; Nyström, 1999). As a result, breeding populations of signal and red swamp crayfishes are now present in many streams of the Basque Country (Rallo and García-Arberas, 2002). In contrast, small populations of the native white-clawed crayfish are found in the Basque Country only in brooks, small springs, and in headwaters of a limited number of streams (García-Arberas and Rallo, 2000). Although spread of the fungus Aphanomyces astaci is the main reason given to explain the disappearance of most native crayfishes from European waters (Diéguez-Uribeondo et al., 1997b; Söderhall and Cerenius, 1999), the decline of these species is also due to habitat loss and habitat degradation (Westman, 1985; Smith et al., 1996; Rallo et al., 2001; Souty-Grosset et al., 2006).

Here we used SWOT analysis to evaluate the situation of the indigenous white-clawed crayfish $A$. italicus in the province of Biscay (Basque Country). The analysis of the Strengths, Weaknesses, Opportunities and Threats (SWOT) is a strategic planning method used to identify the internal and external factors that are favourable and unfavourable to achieve an objective. SWOT analysis is commonly used in the financial and business sectors, and it has also been employed for education purposes in recent years, but it has not yet been applied in environmental studies or conservation. We employed SWOT to evaluate the survival opportunities of a threatened aquatic species under the socio-economic conditions typical of a highly populated region.

\section{MATERIALS AND METHODS}

Basque country is located in the North of the Iberian Peninsula and it is administratively divided in three provinces. The work was carried out in the province of Biscay, a small but much crowed coastal territory with a surface of $2220 \mathrm{~km}^{2}$ and a population density 
of 512 inhabitants $\mathrm{km}^{-2}$. The general conditions of the hydrographic basins of the Basque Country have already been described (Docampo et al., 1991; Rallo, 1992). The streams, belonging to the Cantabrian basins, are short (distance to source is $26.5 \pm 8.0 \mathrm{~km}$, range 3.7 to $35.6)$, with relatively steep slopes $(0.9 \pm 0.3 \%$, range 0.4 to 1.7$)$, and fluctuating flow rates with peak flows in spring and autumn (mean annual flow $=2.7 \pm 3.8 \mathrm{~m}^{3} \cdot \mathrm{s}^{-1}$, range 0.6 to 15.4).

From 1993 to 2007 we sampled more than 600 locations during the summer and early autumn months (July to October). Crayfish presence was detected using a variety of methods. Thus, in small rivers and shallow waters, visual censuses were carried out at night with the help of a head lamp. Nocturnal visual searches were limited to 30 minutes and the length of the fluvial reach covered was recorded. In some cases crayfish were also caught by hand for sex determination and biometric analysis. Non-native crayfish generally inhabit larger and deeper sites, and in these cases baited traps were used and a minimum stream length of $400 \mathrm{~m}$ was sampled.

The following habitat data were recorded at each sampling site: mean wetted width and water depth, hydrogeomorphological characteristics, substrate and riverbank vegetation, and anthropogenic disturbances. In most cases water and macroinvertebrate samples were taken in order to measure other physical, chemical and biological variables.

\section{RESULTS AND DISCUSSION}

The objective of our SWOT analysis was to evaluate the possibilities for the threatened native freshwater crayfish $A$. italicus to survive in Biscay. Therefore, the strengths, weaknesses, opportunities and threats are listed and discussed below (Table I).

\section{STRENGTHS}

From a conservation perspective, the strengths of the white-clawed crayfish are the inherent attributes of the species - internal factors - that will likely help its long-term survival. Molecular data supports a natural origin of $A$. italicus in the Iberian Peninsula (Santucci et al., 1997; Diéguez-Uribeondo et al., 2008). It is obvious that the fact of being an indigenous species helps it in order to be "favoured" in terms of biodiversity conservation. Early controversies about the possible non-native origin of the species have been used as an argument to exclude it from the list of native species, but this is now rarely an issue. Iberian crayfish populations show low genetic variability and limited genetic differentiation (Diéguez-Uribeondo et al., 2008), and may be considered as a single Evolutionarily Significant Unit (ESU) for the purposes of conservation (Moritz et al., 1987). In this sense, crayfish translocations and restocking of Iberian populations are much easier. A. italicus is present in 108 streams In Biscay (Figure 1, Table II), which represents a relatively wide distribution, at least when it is compared to that found in nearby areas (Alonso et al., 2000).

\section{WEAKNESSES}

Weaknesses are the attributes of the species - internal factors - that may hamper its long-term survival. A. italicus is not resistant to the crayfish plague, and has virtually disappeared from the Iberian Peninsula over the past 30 years mainly due to this disease (Diéguez-Uribeondo et al., 1997b). The remaining surviving populations are generally small and fragmented, which would limit their dispersal and make them particularly vulnerable to habitat alterations (Bubb et al., 2008). Although geographical isolation can have some positive effects on crayfish survival, it doesn't offer a sufficient guarantee (Gil-Sánchez and Alba-Tercedor, 2006). In Biscay A. italicus inhabits small, shallow waterways (average wetted width $=1.1 \pm 0.6 \mathrm{~m}$; mean depth $=14 \pm 9 \mathrm{~cm}$ ). Half of the sampled populations were distributed in a fragmented, discontinuous way, in separate stretches or in small ponds, while 


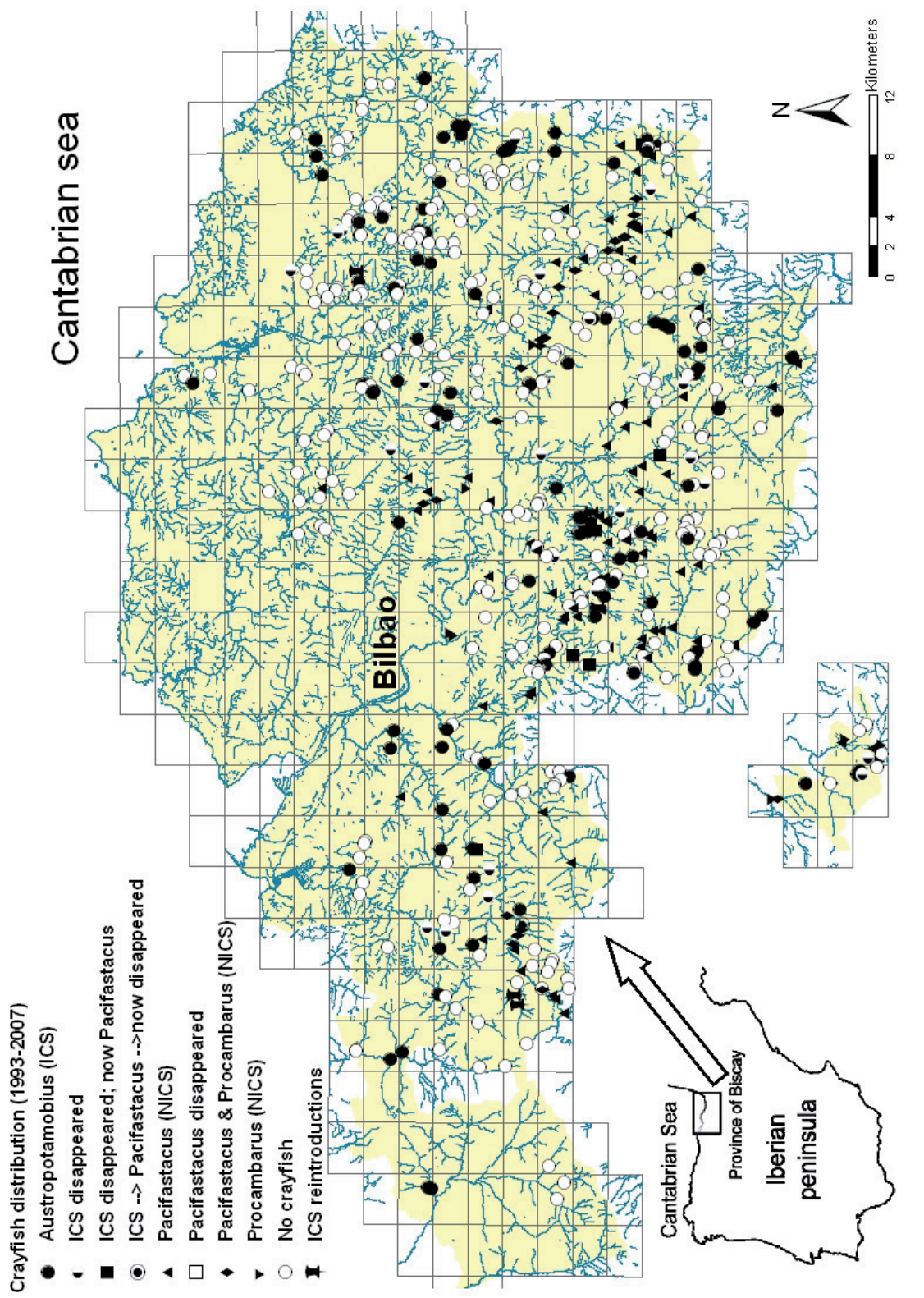

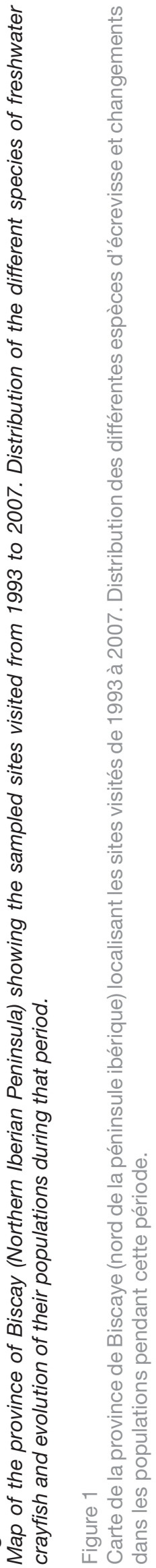




\section{Table I}

SWOT analysis: attributes and conditions of the indigenous freshwater crayfish A. italicus in the province of Biscay (Basque Country, Iberian Peninsula).

\section{Tableau I}

Analyse SWOT : caractéristiques et conditions de l'écrevisse indigène $A$. italicus dans la province de Biscaye (Pays Basque, Péninsule ibérique).

\begin{tabular}{|c|c|c|}
\hline & Internal & External \\
\hline & STRENGTHS & OPPORTUNITIES \\
\hline & $\begin{array}{l}\text { 1) Indigenous species } \\
\text { 2) Relatively high number of populations } \\
\text { 3) Iberian crayfish stock: low genetic } \\
\text { variability } \rightarrow \text { single ESU for conservation }\end{array}$ & $\begin{array}{l}\text { 1) Level of knowledge: distribution, state } \\
\text { of the populations and optimal habitat } \\
\text { 2) Fishing is forbidden } \\
\text { 3) Crayfish plague remains only with crayfish } \\
\rightarrow \text { after disappearance, restocking is possible } \\
\text { 4) Some successful essays of reintroduction } \\
\text { 5) NICS are not introduced anymore } \\
\text { 6) NICS can be fished in a few preserves } \\
\text { 7) European network CRAYNET } \\
\rightarrow \text { contacts between scientists and managers } \\
\text { 8) Riverines are not landowners } \rightarrow \text { easier } \\
\text { management } \\
\text { 9) An increasing environmental "sensibility" } \\
\text { 10) Conservations efforts are greater } \\
\text { in high income countries }\end{array}$ \\
\hline & WEAKNESSES & THREATS \\
\hline & $\begin{array}{l}\text { 1) Not resistant to crayfish plague } \\
\text { (Aphanomyces astaci) } \\
\text { 2) Very small and isolated populations } \\
\text { 3) It is no vertebrate }\end{array}$ & $\begin{array}{l}\text { 1) Charismatic appeal is going down } \\
\text { 2) Local legislation: not cataloged } \\
\text { 3) Little economic effort in management } \\
\text { 4) Few coordination between managers } \\
\text { 5) There are no farms } \rightarrow \text { no exemplars for restocking } \\
\text { 6) Poaching } \\
\text { 7) NICS presence (competition and aphanomycosis) } \\
\text { 8) NICS can be fished in a few preserves } \\
\text { 9) A very crowed territory (512 ind } \cdot \mathrm{km}^{-2} \text { ) } \\
\text { 10) Territory uses: water demand } \\
\text { 11) Land use: forestry pressure (exotic species) } \\
\text { 12) Habitat alteration, disturbance and losing }\end{array}$ \\
\hline
\end{tabular}

in the rest of the cases the whole population was in continuous but short river sections. Although the sampled stretches showed a relative high variability, between 10 and $500 \mathrm{~m}$ long (average $=128.4 \pm 104.1 \mathrm{~m}$ ), in most of these cases were below or near $100 \mathrm{~m}$ long.

The decline of small and isolated populations is common among white-clawed crayfish. An extinction rate of 1.09 population/year is described in Granada (12351 km²; Andalusia, Southern Iberian Peninsula), where 26 populations of $A$. italicus were in the census at the beginning of the study (Gil-Sánchez and Alba-Tercedor, 2006). In Biscay, at least 32 populations have disappeared from 1993 to 2007 (Table II). Crayfish mass mortalities that could have been due to the crayfish plague were not detected, suggesting that other factors must have caused local extinctions. Indeed, habitat alteration was identified as the most likely cause for the disappearance of both native and non-native crayfish from Basque streams (Rallo et al., 2001, 2004). High vulnerability to crayfish plague, but also to habitat alteration, must therefore be regarded as important weaknesses of the native crayfish from the perspective of any SWOT analysis.

Another weakness is the fact that there is rarely support for invertebrate conservation. There is only a weak relationship between conservation status in the IUCN Red List and likelihood of receiving funding for conservation (Sitas et al., 2009). For example, LIFE has co-financed 
Table II

Number of localities visited in the province of Biscay from 1993 to 2007. Distribution of the different species of freshwater crayfish (No. of sample sites with or without crayfish) and changes on the populations observed during that period.

\section{Tableau II}

Nombre de sites visités dans la province de Biscaye de 1993 à 2007. Distribution des différentes espèces d'écrevisses (nombre de sites échantillonnés avec ou sans écrevisses) et changements observés dans les populations pendant cette période.

\begin{tabular}{|l|c|}
\hline Freshwater crayfish populations & No. localities \\
\hline $\boldsymbol{A}$. italicus presence & 108 \\
\hline $\boldsymbol{A}$. italicus disappeared & 32 \\
\hline $\boldsymbol{A}$. italicus reintroductions & 10 \\
\hline First $\boldsymbol{A}$. italicus, now $\boldsymbol{P}$. leniusculus & 7 \\
\hline First $\boldsymbol{A}$. italicus, then $\boldsymbol{P}$. leniusculus, now no crayfish & 2 \\
\hline No crayfish & 312 \\
\hline First no crayfish, now $\boldsymbol{P}$. leniusculus & 4 \\
\hline $\boldsymbol{P}$ clarkii presence & 7 \\
\hline $\boldsymbol{P}$ leniusculus presence & 96 \\
\hline $\boldsymbol{P}$ leniusculus and $\boldsymbol{P}$. clarkii presence & 23 \\
\hline FirstP. leniusculus, now disappeared & 5 \\
\hline
\end{tabular}

some 2750 projects and contributed approximately $€ 1.35$ billion to the protection of the environment since 1992. Projects involving vertebrates (particularly those involving birds) have received most of the funding, and only $11.8 \%$ of funded projects involved invertebrates (http://ec.europa.eu/environment/life/project/Projects/).

\section{OPPORTUNITIES}

Opportunities are those external conditions that can promote or enhance species' survival. There is a good level of knowledge about the distribution and conservation status of freshwater crayfish in Biscay, based on long-term, extensive sampling of more than 600 locations (Figure 1, Table II). Previous studies have shown that both native and non-native crayfish tend to inhabit waters characterised by high $\mathrm{Mg}^{+2}$ and $\mathrm{SO}_{4}^{-2}$ concentrations, but that signal crayfish prefer higher values of $\mathrm{SO}_{4}^{-2}$ than the native species (Rallo and García-Arberas, 2002). As restocking is possible on "empty" streams free of Aphanomyces (Schulz et al., 2002) (Table I), successful reintroductions of $A$. italicus have been carried out in Biscay, using knowledge on water chemistry preferences and individuals from nearby areas out of Biscay.

There are also some conservation opportunities related to legislation. The trade of live nonnative crayfish is now illegal in the Basque Country, making accidental introductions less likely. The government ceased the deliberate introductions of $P$. leniusculus in 1997. Fishing for native crayfish is also banned, and although signal crayfish can be fished in a few stream reserves, these must be sacrificed to minimise the risk of illegal translocations. Nevertheless, the effective fishing pressure is low: fishing periods are short and the activity is developed under accurate supervision in a few preserves with a controlled number of fishermen (e.g. 259 licenses in 2007, with only 7 preserves open for a month in 5 rivers). Although fishing of non-native crayfish may always carry the risk of accidental or deliberate translocations, fishing is considered an opportunity because it entails restoring a traditional fishing resource, and also because fishing for non-native species may lessen illegal fishing of native crayfish (Taugbol, 2004; Jones et al., 2006). Finally, international collaboration can also be considered an opportunity for SWOT analysis, as it allows scientists, managers and other stakeholders to work together on crayfish conservation, as in the EU-network CRAYNET (Souty-Grossset, 2005). 


\section{THREATS}

Threats include those external conditions that hamper or prevent species' survival.

Austropotamobius italicus (as A. pallipes synonym) is included as "vulnerable" in the Spanish Red List of Threatened Species, but as in other countries (Holdich and Pöckl, 2005; Peters and Lodge, 2009), local attitudes and legislation vary among different regions of Spain (http://www.mma.es/). In some regions, the species is classified as "in risk of extinction" and various plans of conservation and restoration have been implemented (Diéguez-Uribeondo et al., 1997a; http://portal.aragon.es/). In the Basque Country, the species is not listed and there are no legal protection plans. Moreover, crayfish management involves many departments from different Administrations (Local, Regional, State, EU), and coordination (essential for the development of effective management plans) is often poor. In Biscay, the historically charismatic appeal of the species to rural societies is on the decline, as society becomes increasingly more "urban" and loses touch with the countryside. Lack of news about native crayfish in the Basque media represents a threat, in contrast to other regions in Spain or elsewhere in Europe, where native crayfish are more appreciated (Reynolds and Puky, 2005). In addition, there is no pressure group rallying support for crayfish conservation in the Basque Country and, consequently, political gains are small and funds allocated to $A$. italicus conservation only modest.

The spread of non-native crayfish represents a threat for the native species due to competition and transmission of aphanomycosis (Alderman et al., 1990; Diéguez-Uribeondo, 2006). In Biscay, there are breeding populations of signal crayfish in the middle reaches of many streams (Figure 1). Large numbers of signal crayfish were introduced by the Administration in Biscay from 1989 to 1997 (738 000 larvae stocked in all basins from 1994 to 1997). Although signal crayfish settled in just one basin (Nervión-lbaizabal), the possibility of translocations is high given the presence of wild populations nearby and the existence of a crayfish fishery. The presence of non-native crayfish is considered an important factor that could be harmful to the survival of the native species (Schulz et al., 2006). Even if some small populations of $P$. leniusculus have disappeared, little or no changes have been observed in the distribution of non-native crayfish in Biscay over the last decade. Colonisation of signal crayfish is rapid in a downstream direction, but colonisation of headwaters is likely to be much slower (Bubb et al., 2004). This means that conservation efforts should be directed primarily towards conservation of native crayfish inhabiting headwaters, as efforts in these areas are likely to be more worthwhile. In that sense, an important restocking effort is needed, but in Basque Country there are not farms and $A$. italicus natural populations are small to be used as a source of crayfish for translocations, so getting exemplars for restocking purposes is difficult in Biscay. In relation to land uses, Biscay is a much crowded territory and water demand in the province is very high for both human consumption an industrial purposes (http://www.uragentzia. euskadi.net/). Water quality in Biscay rivers has improved in recent years, but water flows show a marked decreasing trend (Díaz, 2002). Forestry pressure in Biscay is also very high (EUSTAT: Basque Statistics Office; http://www.eustat.es). More than $40 \%$ of the surface of the Territory consists of forestry plantations, most of them made up of exotic conifers and eucalyptus (Figure 2), which are heavily subsidised by Government. Although forest turnover has decreased in recent years, felling rates have remained relatively stable (Figure 3). Most A. italicus populations inhabit the upper reaches of the basins, where forestry activity is very important and can severely impact the natural habitat of the species. This situation puts conservation of native crayfish in direct conflict with the development of forestry activities, making its conservation particularly difficult.

We have analysed the presence of crayfish in relation to the number and type of different stressors affecting the stream channel (Figure 4). Surveys conducted from 2004 to 2007 reveal that 223 locations considered adequate for ICS were inhabited by A. italicus or empty. Up to $60 \%$ of the locations where $A$. italicus were present were affected by some type of stressor perturbing them, the most frequent being land forestry trails. Both forestry activity and trails use imply erosion of the landscape by water runoff. This way, silting is a common stressor in many locations inhabited by native crayfish, and very high values of suspended solids were 


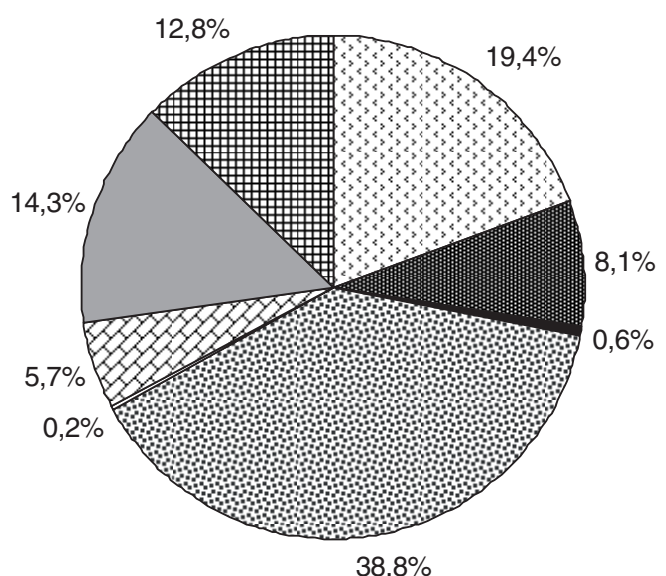

\author{
@ agricultural \\ 国 urban \\ water \\ 图 conífers \\ $\square$ broadleaf plantations \\ $\square$ eucalyptus \\ $\square$ natural forest \\ 囲 other forested areas
}

\title{
Figure 2
}

Land surface distribution in the province of Biscay (total area of the province $2200 \mathrm{~km}^{2}$ ) (Source of data: EUSTAT, 2005).

\section{Figure 2}

Distribution de l'occupation de l'espace dans la province de Biscaye (surface totale de la province $2200 \mathrm{~km}^{2}$ ) (Source des données : EUSTAT, 2005).

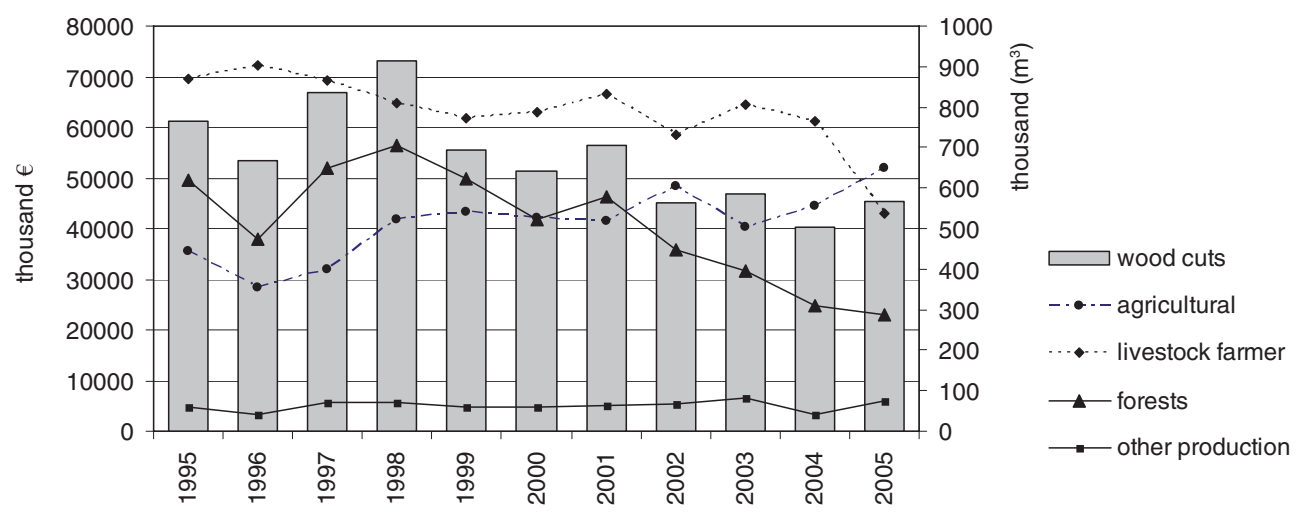

\section{Figure 3}

Final agricultural production by sector since 1995 to 2005 (left) and volume of wood cuts authorised in the province of Biscay (right, thousand $\mathrm{m}^{3}$ ) (Source of data: EUSTAT, 2005).

\section{Figure 3}

Production agricole par secteur de 1995 à 2005 (à gauche) et volume de bois autorisé à la coupe dans la province de Biscaye (à droite, millier $\mathrm{m}^{3}$ ) (Source des données : EUSTAT, 2005).

found $\left(74.3 \pm 46.9 \mathrm{mg} \cdot \mathrm{L}^{-1}\right.$ on average in the streams inhabited by $A$. italicus, but at least $50 \%$ of them showed values greater than $\left.75 \mathrm{mg} \cdot \mathrm{L}^{-1}\right)$. Silting affects the habitat of crayfish and also crayfish directly. Clogging of substrate by silt can significantly reduce juvenile survival (Neveu, 2007), and also damage the gills of crayfish. Other stressors commonly found include habitat alterations due to road works, construction of dams, as well as pollution which is frequent in such a crowded area as Biscay. Such stressors affect all fluvial ecosystem, but tend to be more frequent in the middle and low reaches, so their impact on the native crayfish is lessened. 


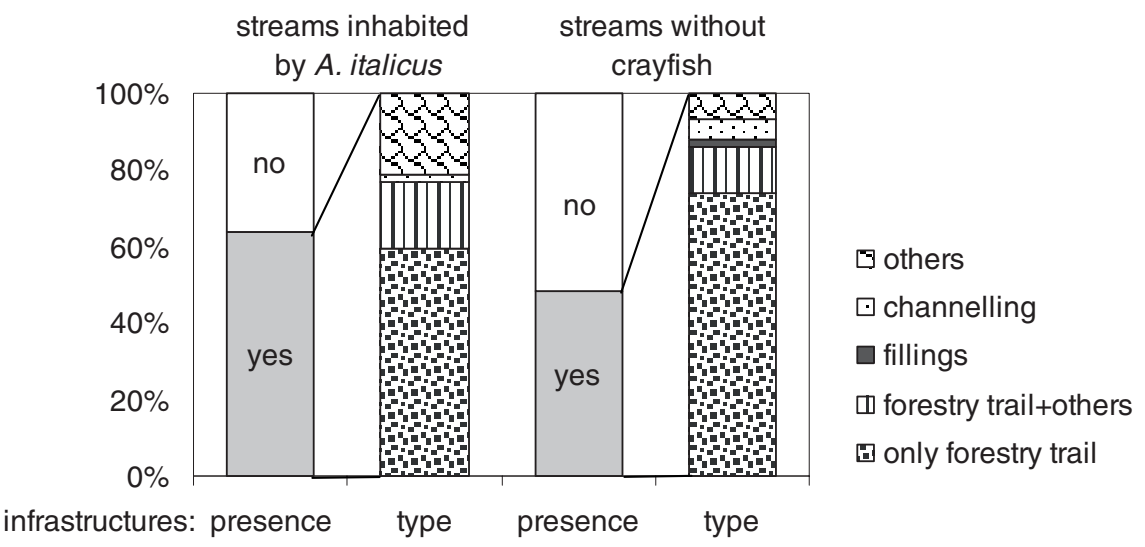

\section{Figure 4}

Occurrence and type of stressors in the streams inhabited by Austropotamobius italicus and in stream reaches without crayfish but considered adequate for ICS. (In "others" water catchments, works on channel, etc., are included.)

\section{Figure 4}

Occurrence et types de stresseurs dans les rivières occupées par Austropotamobius italicus et dans les secteurs de rivières sans écrevisses mais considérés comme propices aux ICS. (Dans les «autres » bassins versants, les travaux sur canaux, etc., sont inclus.)

\section{CONCLUSION}

SWOT analysis has proved useful for identifying those factors most likely to affect the persistence and long-term survival of the native white-clawed crayfish. But what can be done to improve the specie's survival? In classical SWOT analysis the questions become: Can we use and capitalize on each Strength?, How can we improve each Weakness?, How can we exploit and benefit from each Opportunity?, How can we mitigate each Threat? Since strengths and weaknesses are internal factors, and our SWOT aim here is crayfish survival, little or no change appears possible. For example, attempts are being made to breed crayfishes tolerant to the crayfish plague, but low genetic diversity is considered a limitation for captive-breeding of crayfish in the Iberian Peninsula (Diéguez-Uribeondo et al., 2008). Likewise, securing funds for conservation of an invertebrate species is an inherent weakness for crayfish conservation, about which little or nothing can de done. We must, instead, turn our attention to Opportunities and Threats, because they are external to the species, and can be more easily modified. A comparison between opportunities and threats (including five main groups on each: knowledge, legislation, restocking, social parameters and management), reveals an unbalanced scenario where threats seem to outweigh opportunities. The future of freshwater crayfish depends, hence, on the possibility of turning threats into opportunities while, of course, capitalizing on existing opportunities. Several threats to native crayfish conservation in Biscay could be turned into opportunities, including inclusion in the local red list, and raising the charismatic profile of the species, which are already listed as opportunities in nearby areas. Other opportunities include development of legislation rooted by adequate enforcement, better environmental education, and increasing coordination between managers and scientists who have a crucial role to play in crayfish conservation and management (Taugbol and Skurdal, 1999; Meffe et al., 2002; Reynolds and Pucky, 2005). This could be the way to level the balance in order to lead the survival of the native crayfish. The situation of Austropotamobius italicus is critical in the Basque Country. Native crayfish represents an inconvenient species for a pressure economic group (forestry), and its survival is impossible under this scenario. This underlines the need to prioritize and develop conservation measures before species decline to levels from which they cannot recover. Urgent and simultaneous changes are needed in order to turn threats into opportunities. A. italicus should be catalogued in the red list of the Basque Country and protected areas should be established. Other management actions, 
such as changes from existing forest policy to more sustainable forest management practices, are also needed. Finally, dissemination of crayfish status and needs, and public support for crayfish conservation appear essential for the long-term conservation of the species.

\section{ACKNOWLEDGEMENTS}

This work was partially supported by the Diputación Foral de Bizkaia (Dpto. Agricultura). The authors would like to thank the Wildlife Rangers of Biscay for their work on crayfish conservation. Thanks to C. García de Leániz (University of Swansea) for improving the English version of the manuscript. Two anonymous referees offered many helpful criticisms of the manuscript.

\section{REFERENCES}

Ackefors H., 1999. The positive effects of established crayfish introductions in Europe. In: Gherardi F. and Holdich D.M. (eds.), Crayfish in Europe as alien species - How to make the best of a bad situation?, Balkema, Rotterdam Crustacean Issues, 11, 49-61.

Alderman D.J., Holdich D. and Reeve I., 1990. Signal crayfish as vectors in crayfish plague in Britain. Aquaculture, 86, 3-6.

Alonso F., Temiño C. and Diéguez-Uribeondo J., 2000. Status of the white-clawed crayfish, Austropotamobius pallipes (Lereboullet, 1858), in Spain: Distribution and legislation. Bull. Fr. Pêche Piscic., 356, 31-53.

Bubb D., Thom T.J. and Lucas M.C., 2004. Movement and dispersal of the invasive signal crayfish Pacifastacus leniusculus in upland rivers. Freshw. Biol., 149, 357-368.

Bubb D., Thom T.J. and Lucas M.C., 2008. Spatial ecology of the white-clawed crayfish in an upland stream and implications for the conservation of this endangered species. Aquatic Conserv. Mar. Freshw. Ecosyst., 18, 647-657.

Díaz A., 2002. Variabilidad espacio temporal de la calidad fisico-química de las aguas de los ríos de la CAPV. Periodo 1993-2001. Ph.D. Thesis, University of the Basque Country, $468 \mathrm{p}$.

Diéguez-Uribeondo J., 2006. The dispersion of the Aphanomyces astaci-carrier Pacifastacus leniusculus by humans represents the main cause of disappearance of the indigenous crayfish Austropotamobius pallipes in Navarra. Bull. Fr. Pêche Piscic., 380-381, 1303-1312.

Diéguez-Uribeondo J., Rueda A., Castien E. and Bascones J., 1997a. A plan of restoration in Navarra for the native freshwater crayfish species of Spain, Austropotamobius pallipes. Bull. Fr. Pêche Piscic., $347,625-637$.

Diéguez-Uribeondo J., Temiño C. and Muzquiz J., 1997b. The crayfish plague fungus (Aphanomyces astaci) in Spain. Bull. Fr. Pêche Piscic., 347, 753-763.

Diéguez-Uribeondo J., Royo F., Souty-Grosset C., Ropiquet A. and Grandjean F., 2008. Low genetic variability of the white-clawed crayfish in the Iberian Peninsula: its origin and management implications. Aquatic Conserv. Mar. Freshw. Ecosyst., 18, 19-31.

Docampo L., Rico E., Sevillano M., Bikuña B.G. and Rallo A., 1991. Morphology and quantitative analysis of fluvial erosion systems in the hydrological network of the Basque Country autonomous regions. J. Environ. Manage., 32, 251-266.

García-Arberas L. and Rallo A., 2000. Survival of natural populations of Austropotamobius pallipes in rivers in Bizkaia, Basque Country (North of Iberian Peninsula). Bull. Fr. Pêche Piscic., 356, 17-30.

Gil-Sánchez J. and Alba-Tercedor J., 2006. The decline of the endangered populations of the native freshwater crayfish (Austropotamobius pallipes) in southern Spain: It is possible to avoid extinction? Hydrobiologia, 559, 113-122.

Holdich D. and Pöckl M., 2005. Roundtable session 2 - Does legislation work in protecting vulnerable species? Bull. Fr. Pêche Piscic., 376-377, 809-827.

Jones J., Andriahajaina F., Ranambinintsoa E., Hockley N. and Ravoahangimalala O., 2006. The economic importance of freshwater crayfish harvesting in Madagascar and the potential of community-based conservation to improve management. Oryx, 40, 168-175. 
Matthews M., Reynolds J.D. and Keatinge M.J., 1993. Macrophyte reduction and benthic community alteration by crayfish A. pallipes (Lereboullet). Freshw. Crayfish, 9, 289-299.

Meffe G.K., Nielsen L.A., Knight R.L. and Schenborn D.A., 2002. Ecosystem management, Island Press, Washington, $313 \mathrm{p}$.

Moritz C., Dowling T.E. and Brown W.M., 1987. Evolution of animal mitochondrial DNA: relevance for population biology and systematics. Ann. Rev. Ecol. Syst., 18, 269-292.

Neveu A., 2007. Annual variability in reproduction of the white-clawed crayfish (Austropotamobius pallipes): implications for survival. Acta Oecologica, 32, 67-76.

Nyström P., 1999. Ecological impact of introduced and native crayfish on freshwater communities: European perspectives. In: Gherardi F. and Holdich D.M. (eds.), Crayfish in Europe as alien species - How to make the best of a bad situation?, Balkema, Rotterdam Crustacean Issues, 11, 63-85.

Peters J.A. and Lodge D.M., 2009. Invasive species policy at the regional level: a multiple weak links problem. Fisheries, 34, 8, 373-381.

Rallo A., 1992. Caracterización hidrobiológica de la red fluvial de Alava y Gipuzkoa. Gobierno Vasco, Dpto. Medio Ambiente, Vitoria, 511 p.

Rallo A. and García-Arberas L., 2002. Differences in abiotic water conditions between fluvial reaches and crayfish fauna in some northern rivers of the Iberian Peninsula. Aquat. Living Resour., 15, 119-128.

Rallo A., García-Arberas L. and Antón A., 2001. Relationships between changes in habitat conditions and population density of an introduced population of signal crayfish (Pacifastacus leniusculus) in a fluvial system. Bull. Fr. Pêche Piscic., 361, 643-657.

Rallo A., García-Arberas L. and Antón A., 2004. Cambios en las condiciones fisico-químicas y faunísticas de un sistema fluvial (río Oma, Bizkaia), y desaparición de unapoblación de cangrejo autóctono Austropotamobius pallipes: Causa y/o efecto? Limnetica, 23, 49-60.

Reynolds J. and Puky M., 2005. Roundtable session 4 - The importance of public education for the effective conservation of European native crayfish. Bull. Fr. Pêche Piscic., 376-377, 837-845.

Santucci F., laconelli M., Andreani P., Cianchi R., Nascetti G. and Bullini L., 1997. Allozyme diversity of European freshwater crayfish of the genus Austropotamobius. Bull. Fr. Pêche Piscic., 347, 663-676.

Schulz R., Stucki T. and Souty-Grosset C., 2002. Management: Reintroductions and restocking. Bull. Fr. Pêche Piscic., 367, 917-922.

Schulz H., Smietana P. and Schulz R., 2006. Estimating the human impact on populations of the endangered noble crayfish (Astacus astacus L.) in north-western Poland. Aquatic Conserv. Mar. Freshw. Ecosyst., 16, 223-233.

Sitas N., Baillie J.E.B. and Isaac N.J.B., 2009. What are we saving? Developing a standardized approach for conservation action. Animal Conserv., 12, 213-237.

Smith G.R.T., Learner M.A., Slater F.M. and Foster J., 1996. Habitat features important for the conservation of the native crayfish Austropotamobius pallipes in Britain. Biol. Conserv., 75, 239-246.

Söderhall K. and Cerenius L., 1999. The crayfish plague fungus: history and recent advances. Freshw. Crayfish, 12, 11-35.

Souty-Grosset C., 2005. Introduction: The EU-network CRAYNET-impacts on fundamental questions. Bull. Fr. Pêche Piscic., 376-377, 495-503.

Souty-Grosset C., Holdich D.M., Nöel P.Y., Reynolds J.D. and Hafner P. (eds.), 2006. Atlas of crayfish in Europe, Muséum national d'Histoire naturelle, Patrimoines naturels, 64, Paris, 187 p.

Taugbol T., 2004. Exploitation is a prerequisite for conservation of Astacus astacus. Bull. Fr. Pêche Piscic., 372-373, 275-279.

Taugbol T. and Skurdal J., 1999. The future of native crayfish in Europe: How to make the best of a bad situation? In: Gherardi F. and Holdich D.M. (eds.), Crayfish in Europe as alien species - How to make the best of a bad situation?, Balkema, Rotterdam Crustacean Issues, 11, 271-279.

Westman K., 1985. Effects of habitat modifications on freshwater crayfish. In: Alabaster J.S. (ed.), Habitat modification and freshwater fisheries, London, Butterwoths, EIFAC Symposium. 